\title{
A Pragma-Stylistic Study of Implicature in Shakespeare's Hamlet and Twelfth Night
}

\author{
Mohammed Jasim Betti ${ }^{1}$ \& Noor Sattar Khalaf ${ }^{1}$ \\ ${ }^{1}$ Dept. of English, College of Education for Humanities, University of Thi-Qar, Nasiriya, Iraq \\ Correspondence: Mohammed Jasim Betti, University of Thi-Qar, Nasiriya, Iraq. Tel: 0096-4782-7505-317. \\ alseady2@gmail.com
}

Received: August 25, 2021; Accepted: September 1, 2021; Published: September 2, 2021

\begin{abstract}
Implicature is commonly defined as the dissimilarity between what is said and what is meant. The variance lies between the conspicuous meaning of written and spoken words and the meaning that lies beneath what is said. This study aims at analyzing and discussing Shakespeare's Hamlet and Twelfth Night in terms of generalized and particularized conversational and conventional implicature. The model used in the analysis is coined from a variety of pragmatic theories, implicature, Grice's maxims, irony, indirect speech acts, context, and hedges. It is hypothesized that the number of implicature cases in Twelfth Night is bigger than that in Hamlet, generation of implicatures by the characters in the two plays is highly determined by social factors, Hamlet and Cesario use implicature more than other characters, the most used implicature is the particularized one, the purpose of using implicatures differs in the plays, implicature is generated from flouting Grice's maxims and most implicatures are made by violating the relation maxim. The study concludes that the implications in Hamlet are more than those in Twelfth Night, that Shakespeare uses two implicatures generalized and particularized, and that Implicature in Hamlet and Twelfth Night is generated mostly by violating the maxims of quality. As for the least flouted maxim in the two plays is the maxim of quantity.
\end{abstract}

Keywords: Implicature, Hamlet, Twelfth Night

\section{Introduction}

\subsection{Introduce the Problem}

Implicature is the act of saying one thing while meaning another. It is used for communication in situations where there is a difference between what is said and what is meant. Implicatures are used to communicate different ideas and feelings like happiness, sadness, dissatisfaction, pleasure, and so on, formally or informally for different purposes. The understanding of implied expressions depends on the reader's cognition of what is said, the common background knowledge of language and society that both the speaker and the reader share, and context. Context is an essential element for detecting the implicit meaning.

Communication is a process of cooperation to which Grice postulates the cooperative principle. Grice's cooperative principle indicates that all the participants in any communicative act must be cooperative. Accordingly, Grice represents four maxims to support his principle. Any sort of flouting to these maxims results in producing implicatures.

\subsection{Research Questions}

This study addresses the following questions:

1- What are the ways of representing implicatures in Shakespeare's Hamlet and Twelfth Night?

2- Which maxim is highly flouted and which one is flouted the least in Hamlet and Twelfth Night?

3- Does the use of implicature in tragedies resemble that in comedies? And what are the frequencies and percentages of that use of both types?

4- How do the characters achieve implicatures in the selected plays and for what purposes?

\subsection{Aims of the study}

The current study aims at:

1- Identifying the implicatures and the types used in the selected Shakespeare's plays. 
2- Identifying the most and the least flouted maxim(s) in the data.

3- Clarifying the similarities and differences in using implicatures in the data.

4- Building a model for analyzing implicature in the selected literary texts.

5- Finding out the basis on which Shakespeare represents implicature.

\subsection{Hypotheses}

This study hypothesizes the following:

1- The number of implicature cases in Twelfth Night is bigger than that in Hamlet.

2- Generation of implicatures by the characters in the two plays is highly determined by social factors in both Hamlet and Twelfth Night.

3- Hamlet and Cesario use implicature more than the other characters in the plays.

4- The most used type of implicature is the particularized conversational one.

5- The purpose of using implicatures differs in the two selected plays.

6- Implicature is generated from flouting Grice's maxims.

7- Most of the cases of implicatures are made by violating the maxim of relation in the two plays.

\subsection{Limits}

This study is limited to Shakespeare's works Hamlet and Twelfth Night and only to the study of implicature in those texts. The two plays are studied pragmatically in terms of implicature. The selected texts are of edited by Lamb (2000).

\subsection{Significance}

This study is offered by presenting an appropriate and sufficient account of implicatures as a fundamental feature of literary works. It could be beneficial for researchers, language teachers, translators, and for English language learners.

\section{Literature Review}

Literary stylistics is the task of assessing and classifying the range of linguistic choice available to authors, identifying the ways in which features of the linguistic surface of a text may call for themselves. They my obviate the accepted code one way or another in their manner of expression or in other ways to be foregrounded. It is the study of the language of literary works (Dutton, 1984: 73; Al-Seady and Al-Sehlani, 2002: 35).

\subsection{Defining pragmatics}

Huang (2017: 155) introduces pragmatics as being "one of the most vibrant and rapidly growing fields in linguistics and the philosophy of language". He also defines it as "the study of language use in context". What is said is not always clear and direct, the stated speech may sometimes acquire or be affected by the conversational atmosphere; that is to develop the conversation as is required by the situation in which the conversation is being carried on (Baker and Hengeveld, 2012: 84).

\subsection{Definitions and Types of Implicature}

\subsubsection{Definitions}

Two types of meaning exist: referential (the formal logic of dictionary definitions) and conveyed meaning (meaning that is not explicitly stated but can naturally be implied or inferred). Sometimes, the illocutionary force relies on the context and manner in which the words are said. They are said or written with their connotation than their dictionary definitions (Algburi and Igaab, 2021: 34).

Implicature is "to fold something into something else" In order to be clear and perform an understandable act, one must unfold it. Thus, implicature is not something that is said or written directly; it is something which has been left out of the actual use of language" (Mey, 2001: 45).

Levinson makes it clear that implicature is a point of strength to pragmatics as it seeks to explain the linguistic phenomena. This strength comes from the clarification it provides to the semantic content (ibid; and Al-Sheikh, 2006a: 69).

1) A- Can you tell me the time?

B- Well, the milkman has come. 
The above example is meaningless if looked upon from a semantic perspective because B's answer is related only if $\mathrm{A}$ is familiar with the time of the milkman's arrival. The answer is not stated directly and needs further interpretation from A. Speakers may imply something relying on their beliefs and consequently Hearers may interpret what is implicated according to their assumptions about what is said (O'grady and Archibald, 2016: 207).

2) a- Have you stopped exercising regularly?

b- Have you tried exercising regularly?

The speaker in the above sentences presupposes that the hearer has been exercising regularly.

The gap that is created between what is said and what is meant can be bridged by inference. Inference can be made not only by hearers but also by all the participants in the conversational interaction (Dong and Zhang, 2020: 19). Inference is a language strategy that has proven to be very useful in meaning interpretation because humans are programed to infer the implicit meaning of any given discourse by bringing its context and literal meaning together (ibid).

Leech (1983) as quoted in Black (2006: 26) clarifies implicature as a result to breaching the maxims rather than obeying them. He makes it clear that the process of coding and encoding is a responsibility of both the speaker and the hearer (Betti, Igaab and Al-Ghizzi, 2018: 255).

\subsubsection{Types of Implicature}

The types of implicatures include conversational and conventional:

\section{Conversational Implicature}

Grice's investigation of the relation that holds between meaning and context is introduced in his theory of conversational implicature (Riemer, 2010: 116):

3) Arthur: Can you tell me where the post office is?

Bill: I'm a stranger here myself.

Bill's answer implies that he cannot tell, but this intention is not shown in the content of the sentence (Kroeger, 2019: 140).

Brown and Miller (2013: 222) define conversational implicature as "inferences that enable interlocutors to go beyond what speakers say to what speakers actually mean. The inferences are not part of the truth conditions of propositions neither conveyed by utterances nor based on the assumption about speakers following the maxims of conversation":

4) A: Is Jane a good cook?

B: Her mother is a good cook.

B implies that Jane is not a good cook, this inference that is indirectly proposed by B is called conversational implicature (ibid).

There are three ways that Allott (2010: 47) and Paltridge (2012: 51) put forward by which conversational implicature can be created which are as follows:

1- All the maxims should be fulfilled: implicature can arise when the speaker follows the maxims fully and completely:

5) A: Hi. What would you like?

B: Two hundred grams of the shaved ham thanks.

In the above example, all the conversational maxims are fulfilled as both the speaker and hearer observe the purpose of the conversation and act accordingly (Paltridge, 2012: 51).

2- A clash between maxims: the lack of adequate evidence may cause the maxims to overlap; the inability to provide the required amount of information (quantity) is caused by the lack of evidence that verifies the given information (quality) (ibid).

3- Flouting the maxims: a complete violation of the maxims with no intention to mislead gives rise to implicatures. For example:

6) A: I am out of petrol.

$\mathrm{B}$ : There is a garage round the corner.

In this case, A must infer that the garage sells petrol (Geurts, 2010: 9). 
Implicature is of four types which are:

1- Generalized conversational implicatures (GCIs): this type of implicature does not need to rely on contextual conditions (Yule, 1996: 130):

7) Doobie: Did you invite Bella and Cathy?

Mary: I invited Bella.

Here, the information provided in the context does not control the inference, the implicated meaning is that Mary did not invite Cathy (ibid: 40).

2- Particularized conversational implicatures(PCIs): this type is controlled by a very specific context (Birner, 2013: 65):

8) Ann: Where are you going with the dog?

Sam: To the V-E-T.

The word vet is spelled out in order not to be recognized by the dog; spelling the word out as V-E-T implies the meaning (Yule, 1996: 43).

3- Scalar conversational implicatures(SCIs): the speaker in this type adheres to the maxim of quantity (Bianchi, 2013: 118):

9) I am studying linguistics and I've completed some of the required courses.

Speakers tend to use informative and truthful expressions when speaking like the word some in the above example which gives rise to scalar CI (the speaker has not finished all the required courses) (Yule, 1996: 41).

4- Conventional Implicature

Cruse (2006: 36) defines conventional implicature as "components of the meanings of utterances which are not propositional in nature, but have stable associations and which therefore cannot be cancelled".

Levinson (1983:127) provides four conventional expressions: but, yet, therefore and even . A fifth expression for was added by Thomas (1995: 57):

10) She plays chess well, for a girl. (Thomas, 1995: 57)

11) Pete has not registered yet. (Cruse, 2006: 36)

12) Even John came to the party. (Yule, 1996: 45)

\subsection{Grice's Maxims of Conversation}

Language is a powerful means of human communication. Via using language, the sender can deliver his/her intended meaning to the receiver. According to Grice, the communicative activity should go smoothly and straightforwardly. Thus, Grice postulates the cooperative principle in that people should be cooperative in their communication (Betti and Yaseen, 2020: 43). As a result, Grice supports the cooperative principle by four maxims, which speakers should follow (Curzan and Adams, 2012: 245; Schmitz, 2008: 31; and Leech, 1983: 8):

1- The Maxim of Quantity

The contribution made by the speaker must be informative, saying what suffices the situation no more no less than is required (Paltridge, 2012: 44). This maxim is interested in what is actually being said in the text (Locastro, 2012: 49). Saying something more or less than is required will lead to a violation of the maxim.

13) A-Why did you leave the meeting! ?

B-I wanted to.

Here the maxim of quantity is being violated because $B$ hides more than what $\mathrm{s} / \mathrm{he}$ says and is not being informative enough and this affects the meaning as a result (Leech, 2014: 312).

2- The Maxim of Quality

This maxim is concerned with the speaker's credibility. The speaker must say that which is true. It involves two sub-maxims:

1- Do not say what you believe to be wrong.

2- Do not say that for which you lack adequate evidence (Sibsa and Turner, 2013: 111):

14) Mother: Did you study all day long? 
Son: Yes, I have been studying until now!

The son has been playing all day. So, he is lying and therefore violates the maxim of quality in which the speaker must convey true information (Khosravizadeh and Sadehvandi, 2011: 122).

\section{3- The Maxim of Relation}

This maxim involves for the speaker to be relevant to the subject of conversation, for example:

15) A: Can you tell me the time?

\section{B1: I T'S 11:20.}

B2: Well, the milkman has come.

The answer of B1 is direct and gets to the point and requires little or non-deduction, while the answer of B2 is indirect, drifts away from the subject of the question and requires A'S inference (Li, 2015: 41).

The floating of the maxim of Relation in this example results from the speaker's uncertainty of what he is saying, whether it is relevant or not (Yule, 1996: 38-9).

\section{4- The Maxim of Manner}

This maxim involves four sub-maxims as follows:

1- Avoid obscurity.

2- Avoid ambiguity (this means "ambiguity" in context).

3- Avoid unnecessary prolixity (i.e. excessive wordiness).

4- Be orderly (this means that if time relations are not explicitly expressed, events should be related in the order in which they occur) (Cruse, 2006: 10).

16) This may be a bit confused, but I remember being in a car.

The violation of the maxim of manner stems from the vagueness of the speaker's statement since it is not clear whether s/he is in the car now or not (Yule,1996: 38-9; Al-Seady, 1998: 88).

Grice (1975) as quoted in Bousfield (2008: 22) says that "utterances that are the concern of the maxim of manner relate not to what is said but to how what is to be said is said".

\subsection{Observing and Violating the Maxims}

\subsubsection{Observing the Maxims}

In his theory of meaning, Grice makes it clear that for comprehending the speaker's meaning, it is important to recognize his intention (Christie, 2000: 130). Grice's theory is mainly about supplying an approach of the way meaning is conveyed through an indirect act which explains the relationship between the maxims and those who are being engaged in a conversation (Allan and Jazczolt, 2012: 277).

The type of verbal interaction in a conversation is what determines whether a speaker is to be obedient and to follow the maxims or not. For instance, a suspect in custody would unlikely to be expected to tell the whole truth to a police officer, this is related to the formulation of the cooperative principle itself (kortmann, 2020: 186). The following examples clarify how the maxims are observed in a conversation (Igaab and Al-Manhalawey, 2010: 39):

17) A: What would you like?

B: A beer thanks.

18) A: Hi. what would you like?

B: Two hundred grams of the shaved ham thanks.

The conversational maxims are all being observed in the above examples as follows:

1- The maxim of quantity is observed by B as s/he is saying exactly the required amount of information and is being as informative as required.

2- The maxim of quality is observed as B is truthful.

3- The maxim of relevance is observed as B's answer is relevant to A's question.

4-The maxim of manner is observed as B's answer is brief and clear (Thomas, 1995: 64 and Paltridge, 2012: 44, 51). 


\subsubsection{Violating the Maxims}

All the participants in a talk exchange are said to cooperate with each other and take into consideration the cooperative principle as an essential postulation and try to make an appropriate contribution (ibid: 128). In order for a participant to be cooperative, s/he has to speak truly, relevantly, clearly, and be informative (Levinson, 1983: 102).

There are many situations and occasions where speakers fail to observe the maxims intentionally and nonintentionally which can be represented in different ways as follows:

\section{1- Flouting:}

Bahrami (1999: 87) states that: "flouting is one kind of implicature [which]comes about by overtly and blatantly not following some maxim, in order to exploit it for communicative purposes". The speaker's violation of a maxim in this case is intentional:

19) A: Smith does not seem to have a girlfriend these days.

B: He has been paying many visits to New york lately.

In the above example, $\mathrm{B}$ deliberately flouts the maxim of relation and provides no information of suggesting that Smith has a girlfriend in New York. B intends to mislead A (Kroeger, 2019: 144).

The understanding of what is meant may sometimes result from an intentional flouting of the cooperative principle. It is difficult to decide what maxim is being in use and which is not. It is considered a problematic matter that the cooperative principle suffers from. This overlapping between the four maxims is shown in the following example:

20) A: What did you have to eat?

B: Oh, something masquerading as a chicken chasseur.

It is obvious that the answer is relevant to the question but B's answer flouts the maxim of quantity by not giving the necessary amount of information, the maxim of manner by not saying what he has to eat clearly, and the maxim of quality by not saying the truth (Cutting, 2002: 42).

Thomas (1995: 65) indicates that implicature is produced deliberately when the speaker intends to flout or violate a maxim intentionally with no aim to mislead the hearer but with the intention to urge the hearer to look beyond the expressed meaning.

2- violating: the speaker intends, in violating a maxim , to mislead the hearer. For example:

21) Teacher: Why did not you do your homework?

Student: May I go and get some water? I am so thirsty.

The maxim of relation is violated by the student by giving an irrelevant answer with the aim of misleading the teacher to avoid the consequences of not doing the homework (Khosravizadeh and Sadehvandi, 2011: 122).

3- Opting out: This refers to the total refusal to cooperate in a conversation. The speaker may opt out the maxims all together:

22) A: ... um I lived in uh a country where people sometimes need to flee that country.

B: uh, where was that?

A: It is a country in Asia and I do not want to say any more.

The maxim of manner is opted out by A because $\mathrm{s} / \mathrm{he}$ is not being clear, $\mathrm{s} / \mathrm{he}$ opts out the maxim of quantity by providing more information than is required. Likewise, speakers may choose to opt out the maxims for ethical reasons, to avoid hurting a third party, to avoid endangering others, or other reasons (Thomas, 1995: 75; Salman, and Betti, 2020: 225).

4- A clash between the maxims:

The maxims may overlap on some occasions. A particular utterance might be detailed and unclear. In the following example, there is a breach of both quality and quantity maxims (Paltridge, 2012: 47):

23) A: Where does $C$ live?

B: Somewhere in the south of France. (Senfit, 2014: 35)

Awareness of the cooperative principle and its four maxims are requirements that fall on the part of the participants (Strassler, 1982: 61). 
Burke (2014: 126) introduces two ways of generating the implied meaning:

1- Flouting a maxim intentionally during a conversation.

2- Violating a maxim where the speaker misleads the hearer in a covert way (with no intention for the hearer to figure out that a maxim is broken).

Direct and indirect speech acts are similar and different at the same time:

24) John said ,"I am tired."

25) John said (that) he was tired.

Although the two previous examples are similar in verb, subject, and the content of the speech act but they differ in form. Transformationalists propose that (26) should be derived from (25) as a transformation called "indirect discourse formation" (Li, 2015: 29).

When speakers implicate something, they mean to communicate more than what is said. This process indicates that there are two or more cooperative parties involved in a conversation (Akmajian et al. 2001: 399). Implicature (implied meaning) cannot be separated from what is said; it highly depends on the way the expression is put forward (Grice, 1989: 271).

Explicature on the other hand, is a term that is introduced "to characterize the speaker's explicit meaning in a way that allows for richer elaboration than Grice's notion of (what is said)" (Wilson and Sperber, 2012: 11). Grundy(2000: 102) defines explicature as "an enrichment of an original utterance." He adds that explicature and implicature are only ways that ease the comprehension of what is said (ibid: 115).

\subsection{Implicature and Related Terms}

\subsubsection{Implicature and Irony}

Ricoeur (1977: 110) defines irony as a method in which one shows something that is the opposite of what he actually says. Thus, irony represents the difference or contrast between what is said and what is meant (Black, 2006: 110). It is a word or a phrase in which the intended meaning by the speaker differs from the superficial one (Hebron, 2004: 183). Irony then is a way of communicating thoughts and ideas in a sarcastic way (Carston, 2002: 378).

The most outstanding types of irony are as follows:

1- Verbal irony represents a contrast between what is said and what is meant and an apposition between whether the meaning is implicit or explicit. It could be Sarcasm, Bathos, Pun, Understatement, overstatement, Hyperbole (Eastman, 2009: 179; Betti, 2015: 50).

2- Romantic irony refers to fiction and reality discrepancy and is used in literary works. It is difficult to be put in a category because it represents comedy and seriousness at the same time (Ellestrom, 2001: 52)(Fischer and Greiner, 2007: 16).

3- Situational irony: is a type that is understood as a situation where a contradiction is made between what is expected and what actually results (Ellestrom, 2001: 51; and Betti (2015: 52).

4-Structural irony: it is a situational irony that is put into words, it involves contrast and is text specific (Ellestrom, 2001: 51).

Ironic expressions are said to be uttered in an intentional flouting to the conversational maxim of quality (Mufwene et al., 2005: 411).

\subsubsection{Implicature and Context}

Context is the mutual cognitive context, or salient common ground. It includes the current state of the conversation (what has just been said, what has just been referred to, etc.), the physical setting (if the conversants are face to face), salient mutual knowledge between the conversants, and relative broader common knowledge. (Bach, 2010: 21)" (Meibauer, 2012: 10).

Clark (2001: 1) defines context as the environment or the setting where the conditions are related to each other and allows something to exist or occur. Context is the setting where a particular activity takes place. The context of irony, for example, is the setting where the ironic expression is uttered. In an ironic situation, the context includes the participants, the relationships between them, and the cultural context realized by the participants (Barbe, 1995: 77). 
Context plays a role in the distinction between semantics and pragmatics as it, alongside presupposition and Grice's implicature, incorporates into theories related to semantics and pragmatics (Stalnaker, 2014: 13). The conversational situation includes a group of participants with common beliefs and purposes; participants are said to be in the same context when one asks a question and another answers even if the subject and the common beliefs are changing throughout the conversation (ibid: 14).

The identification of the intended speech is only possible by the aid of the context where the hearer determines what is meant by the speaker's actual utterance (Schiffer, 1972: 49). It is almost impossible to specify what is stated and what is implied without the context which leads to communication failure (Grundy, 2000: 72). Context is treated as a number of information that is accessible and conspicuous in the physical environment while in fact it is a common ground where conversations take place (ibid: 107).

Pollock (2020: 246) explains that different authors adopt different methods to describe a successful communication act depending on context. Some authors introduce the approach of shared content by which they proclaim that a hearer must realize the same message conveyed by the speaker in order for the conversation to be communicatively successful. Others claim that a successful communication demands similarity of the context expressed by the speaker and is inferred by the hearer. These two adopted approaches are in fact two distinct pictures of the communicative success (ibid; Igaab, 2010: 169).

Malinowski (1923: 306; cited in Widdowson, 2004: 37-38) thinks of utterances to be meaningless unless they appear in the context of situation. Hymes (1968: 105; quoted in Widdowson (2004: 38) and Betti, and Igaab (2018: 30) say that when a form is used in a context, it eliminates the meanings possible to that context other than those the form can signal: the context eliminates from consideration the meanings possible to the form other than those the context can support.

Context is of two types; context of situation refers to "the immediate environment in which a text is actually functioning" and the context of culture which is "a broader background against which the text has to be interpreted" (Halliday and Hasan, 1989: 46-47).

\subsubsection{Implicature and Indirect Speech Acts}

Indirect Speech Acts is one of Searle's contributions to SA theory. It is an utterance that has the form of a certain illocutionary act but it has the meaning of another type (Searle, 1979, p. 30). For example, the utterance below may be interpreted literally to ask the hearer about his ability to carry out action or non-literally to request him to do an action for the benefit of the S.

26) Can you open the window? (Betti and Hasan, 2020: 49).

Grice represents a differentiation between direct meaning (an utterance carries meaning and if true provides an entailment) and indirect meaning (an utterance provides no entailment to the recipient) with the intention to conceive the possibility that the modification of direct meaning results in something like the indirect meaning because he thinks that the latter is the one that needs more demonstration (Feng, 2010: 11).

Searl (1979: 31-32) hypothesizes that speakers communicate by using indirect speech acts by relying on the common linguistic and non- linguistic background information and on the hearer's ability to infer the intended meaning.

Indirect acts do not need a literal base in order to be performed and can be represented by speaking nonliterally. The difference between direct and indirect speech acts is shown by Collavin (2011:379) in the following examples:

27) I killed them. (indirect speech act)

28) I confess that I killed them. (direct speech act)

Indirect speech act is an act achieved by implicature. It can be defined (following Searl 1975) as "an utterance whose form does not reflect the intended illocutionary force." (Kroeger, 2018: 180- 186). A successful indirect speech act must be attached to the felicity conditions of the primary act which are preparatory, sincerity, propositional and essential condition (ibid).

\subsubsection{Implicature and Hedges}

Lakoff (1972) defines hedges as words or expressions that "make things fuzzier or less fuzzy" and weaken the proposition's force by using some linguistic strategies or linguistic markers and for authors (Kranich, 2016: 33). It is the use of words or phrases to refer to the speaker's uncertainty of what $\mathrm{s} /$ he says whether it is correct and complete or not and that what is reported is something that the speaker "think or feel (not know), is possible (not certain), and may (not must) happen as in He's sort of nice, or the full force of a speech act, as in I must ask you to 
stop doing that." (Fraser, 2010: 15). " Examples of hedges that people use to start a conversation like: As far as I know..., Correct me if I am wrong, but..., and I am not absolutely sure, but... (ibid).

The use of hedges in texts results in indirectness and vagueness. (McCready, 2015: 37). Their use makes speakers communicate things that are not certain of. Speakers using hedges and turn out to be wrong violate Grice's maxim of quality by saying false things or things for which they lack evidence (Igaab, 2015: 139):

29) I suspect that it is cold outside.

30) John is sort of stupid.

Expressions like (suspect that and sort of) are used to save the speaker from being wrong and to reduce the impact of what is said on the hearer (ibid: 39). They may also involve reinforcement:

31) I really love you. (Fraser, 2010: 16-17).

\section{Method}

\subsection{Data Description}

The data consists of Shakespeare's Hamlet and Twelfth Night. The texts used for analysis are edited by Lamb (2000). Hamlet is Shakespeare's first outstanding tragedy. Twelfth Night is one of Shakespeare's well- known, lightest, and the most musical romantic-comedy play.

\subsection{Model of the Study}

This model is an eclectic one coined from a variety of theories in pragmatics. It consists of the model to be applied and the factors taken into consideration for text interpretation:

\subsubsection{Model of Application}

\section{1- Implicature}

Implicature refers to the possibility of meaning more than what is literally said (Blackwell, 2003: 12). It is represented by the speaker to the hearer by implicating rather than stating (Saeed, 2016: 210).

It is used in both writing and conversation (Griffiths, 2006: 134). It is a result of breaking Grice's maxims rather than following them. The interpretation of what is implied is the responsibility of the hearer but this does not eliminate the speaker from being part of the process. The speaker should perform an appropriate linguistic expression (Black, 2006: 26).

\section{2- Grice's Maxims}

Grice represents four maxims of conversation (quality, quantity, relevance, and manner). The observance of these maxims leads to cooperation and non-observing a maxim gives rise to implicatures (Kroeger, 2018: 144).

These maxims can be applied to different kinds of texts and violating them does not lead to any meaning damages, as well as, it is quite possible for the maxims to interfere with each other (Leech, 1983: 8).

\subsubsection{Theories for Interpretation}

The theories used for understanding and interpreting the meaning of the texts include the following:

\section{1- Irony}

For people to use ironic expressions, they must say something and imply another and this depends on the common awareness of the English usage by the speaker and the hearer (Allan, 1989: 4-5). Irony is generated by breaking Grice's maxims intentionally to communicate something (Black, 2006: 25). Implicature arises from the use of irony as it requires an implication for it to utter (Al-Sheikh, 2006b: 71).

2- Indirect speech acts

It is possible for a speaker to say something and imply something else by using indirect speech acts relying on the linguistic background of participants and on the recipients' ability to interpret the intended meaning (Searl, 1979: 31-32).

\section{3- Context}

The way context is relied upon in meaning interpretation is a field studied in pragmatics. It is affected by the information that is known by the speaker and assumes that the hearer is familiar with (Cook, 1989: 10). Context is important in generating implicatures because it determines the way readers interact and infer meaning from texts and conversations (Verdonk, 2013: 9). 


\section{4- Hedges}

They offer interlocutors a way to avoid conversational commitment as the speaker does not give definite information that could entangle him (Hyland, 1998: 1).

Hedging is an act represented by implicature. Implicated or hedged texts require language structure for the sake of reading the text properly and knowledge structure for interpreting the read text (Yule, 2020: 176-177).

\section{Results}

\subsection{Analysis and Discussion of Implicature in Hamlet}

There are twenty-nine cases of implicature available in Hamlet. This section is devoted for presenting the interpretation and text analysis of implicature cases. Seven examples are given for each play:

Text (1):

King: How is it that the clouds still hang on you? (I, ii, 66).

The king is asking Hamlet why the clouds are pending over him. The question is not made directly but by implicating that Hamlet looks so sad. This particularized conversational implicature is made by flouting the maxim of manner by being ambiguous. The king is of high social class, and there is something hidden in himself; that is why, he produces implicature.

Text (2):

Hamlet: Not so, my lord; I am too much I' the sun (I, ii, 67).

Hamlet's answer to the King's answer in text (1) involves an implicature as he is not referring to himself being literally in the sun but to refer to the clarity of his personality, he is the son of the late king, and that he is now enlightened by the truth about his father's murder. Hamlet's answer indirectly represents generalized conversational implicature made by violating the maxim of relation because he is not referring to the same subject referred to by the king. Similar to what has been said about the king, Hamlet produces an implicature because he is a prince and has some secret bout the death (murder) of his father.

Text (3):

Queen: Thou know'st 'tis common; all that live must die,

Passing through nature to eternity.

Hamlet: Ay, madam, it is common. (I, ii, 73- 76).

The queen (Hamlet's mother) is trying to ease Hamlet's pain and urge him to decline his sorrow. She refers to death as a common thing among humans and that every living creature is destined to death. Hamlet's partial repetition of his mother's speech indicates his politeness but in fact, he ironically implicates his disagreement because it is not actually common. Hamlet's generalized conversational implicature is made by violating the maxim of quality by not telling the truth about his feelings. It is actually not common.

Text (4):

Polonius: What do you read, my lord?

Hamlet: "Words, words, words" (II, ii, 190- 191).

The dialogue occurs between Polonius and Hamlet when Hamlet is reading a book and Polonius asks him about what he is reading. Hamlet's answer implies that what he reads is mere words without actions. Hamlet's answer is actually a description of the way he sees himself, a man of words without actions. He thinks that his hesitation and delay in avenging his father's murder is just as useless as words on a piece of paper. This particularized conversational implicature is indirectly made by violating the maxim of quality (not truly states what he intends). Hamlet refers to himself as a man of words not of actions.

Text (5):

Ophelia: you are merry, my lord.

Hamlet: Who, I?

Ophelia: Ay, my lord.

Hamlet: "O GOD, your only jig-maker! What should a man do but be merry? For look you how cheerful my mother looks, and my father died within two hours," (III, ii, 124- 130). 
Ophelia asks Hamlet if he is happy. Hamlet answers her that everyone should be happy which is not real but is an attempt to assure his madness and pretend to be happy. He refers to his mother's happiness in her new marriage though his father's death is as if it was two hours earlier. Hamlet implicates that he has not been happy since the death of his father and yet, his mother is happy and married again. Generalized conversational implicature is ironically made by violating the maxim of quality, as Hamlet does not state his true feelings, he is so sad and desperate man who pretends to be happy.

Text (6):

Hamlet: I will speak daggers to her, but use none;

My tongue and soul in this be hypocrites;

How in my words soever she be shent,

To give them seals never, my soul, consent! (III, ii, 401- 404).

Hamlet, in his soliloquy, is promising himself not to hold back anything and that he is going to speak his true feelings out to his mother. He describes his words to be daggers to his mother. He implicates that his words are going to hurt his mother so bad as if she was hit with daggers. This particularized conversational implicature is contextually made by violating the maxim of quality because Hamlet is not telling the truth about speaking daggers.

Text (7):

King: Is there not rain enough in the sweet heavens

To wash it white as snow? (III, iii, 46- 47).

In a soliloquy made by him, the king confesses his guilt of killing his brother and seeks a way to repent this awful deed. He wonders if there is not enough rain in the sky to wash the guilt away from his hands. The king implicates that he is the killer of his brother and the feeling of guilt and remorse is stuck on him and that what has been done is irredeemable. This particularized conversational implicature is contextually made by violating the maxim of quality because he is the killer of his brother and killing is something where there is no coming back from.

Table (1) below shows that generalized conversational implicatures are more in number than the particularized ones in Hamlet while there is only one case of conventional implicature:

Table 1. Types of Grice's Maxims Violated Implicature in Hamlet

\begin{tabular}{lll}
\hline Types of implicature & Occurrence number & $\%$ \\
\hline Generalized conversational implicature & 15 & 51.72 \\
Particularized conversational implicature & 13 & 44.82 \\
Conventional implicature & 1 & 3.44 \\
Total & 29 & 100 \\
\hline
\end{tabular}

Table (2) below shows that the most flouted maxim in the play is the maxim of quality because the subject of the play depends on conspiracies and the least flouted maxim is the maxim of quantity because a character like Hamlet who seeks revenge against his Father's killers is not likely to be direct and informative about his intentions:

Table 2. Violating Grice's Maxims in Hamlet

\begin{tabular}{lll}
\hline $\begin{array}{l}\text { Flouted } \\
\text { maxims }\end{array}$ & $\begin{array}{l}\text { Occurrence } \\
\text { number }\end{array}$ & $\%$ \\
\hline Quality & 15 & 51.72 \\
Quantity & 0 & 0 \\
Manner & 7 & 24.13 \\
Relation & 7 & 24.13 \\
Total & 29 & 100 \\
\hline
\end{tabular}

In this regard, verbal ironic speeches flout Grice's maxims in Shakespeare's Hamlet and all the politeness maxims are exploited for the purpose behind using irony (Betti and Mirdas, 2016: vii).

Table (3) below shows that the characters who produce implicature in Hamlet are educated and of a high class: 
Table 3. Characters and Implicature in Hamlet

\begin{tabular}{lll}
\hline Characters & Number of cases & $\%$ \\
\hline Hamlet & 21 & 72.41 \\
The king & 5 & 17.24 \\
Polonius & 2 & 6.89 \\
Francisco & 1 & 3.44 \\
Total & 29 & 100 \\
\hline
\end{tabular}

Hamlet is the representative character that produces the larger number of implicatures because of his confusion about the situation he is involved in and his obligation to fulfill his destiny by taking his revenge. In addition, he is prince and has some inner secrets about his father's death. Shakespeare weaves stories by representing historical and imaginary characters. All Shakespeare's characters are equally essential to the development of theme, plot and characterization. Shakespeare portrays the characters and all the other aspects of Hamlet so knittedly and skillfully (Betti, 2013: 14).

\subsection{Analysis and Discussion of Implicature in Shakespeare's Twelfth Night}

This section is devoted for the interpretation and text analysis of implicature cases. There are twenty-eight cases of implicature available in Twelfth Night. Seven examples are given for Implicature in this play.

Text (1):

Olivia: Now, sir, what is your text?

Cesario (Viola): Most sweet lady_

Olivia: A comfortable doctrine, and much may be said of it.

Where lies your text?

Cesario (Viola): In Orsino's bosom.

Olivia: In his bosom? In what chapter of his bosom?

Cesario (Viola): To answer by the method, in the first of his heart.

Olivia: $\mathrm{O}$, I have read it, it is heresy. Have you no more to say?

(I, iv, 201- 209).

Viola disguised as Cesario arrives at Olivia's palace as Orsino's messenger. In all romantic comedies, the male character is unimportant compared to the female one (Betti, 2002: 28-9). Cesario (Viola) tells Olivia that he wants to reveal his massage to her privately. Olivia orders her staff to leave them alone. After everybody's departure, Olivia asks Cesario to show his message and he answers that it is in Orsino's bosom. Cesario implicates that he is carrying Orsino's love which is, so big that no words and papers would be enough to describe it. This particularized conversational implicature is made by flouting the maxim of quality. Love is in Orsino's bosom means love is in his heart. Here, because Viola, Orsino and Olivia have secrets in their lives and are of aristocratic origin, they have implicatures.

Text (2):

Olivia: O sir, I will not be so hard- hearted. I will give out divers

Schedules of my beauty. It shall be inventoried and

every particle and utensil labelled to my will: as, item

two lips indifferent red, item two gray eyes, with lids to

them, item one neck, one chin, and so forth. Where you

sent hither to praise me? (I, v, 223-228).

Olivia answers Cesario's speech that she is not so heart- hearted and she is going to leave a list of her descriptions. Her reply is an implication that she is not going to marry. This generalized conversational implicature is ironically made by giving details of human body, she violates the maxim of quality because Olivia is not being truthful.

Text (3):

Sir Andrew: Here comes the fool, I'faith. 
Feste: How now, my hearts? Did you never see the picture of

"We Three"? (II, iii, 13- 15).

Sir Andrew and Sir Toby are drinking at midnight and talking none sense when Feste(the clown) enters. Sir Andrew says here comes the fool, Feste replies asking them weather they have seen the picture called "We Three". This generalized conversational implicature is made by violating the maxim of quality. He implicates that the three of us are fools. Here, we have irony because of Feste (the clown) in Shakespeare's plays.

Text (4):

Malvolio: Mistress Mary, if you prized my lady's favour at

anything more than contempt, you would not give

means for this uncivil rule. She shall know of it, by this

hand. [He Exits.]

Maria: Go shake your ears! (II, iii, 111- 115).

Malvolio is upset by the noise that Sir Andrew, Sir Toby, and Feste are causing in the middle of the night. He orders them to stop at once but they are too drunk to respond and continue their party. The three asks Maria to bring them more wine but Malvolio stops her and tells her to leave their company or she will face Lady Olivia's punishment. Maria tells Malvolio to go wiggle his ears. She implicates that Malvolio is as a donkey who shakes his ears when having nothing to do. The implication indicates Maria's social class as she uses impolite words in her answer. This particularized conversational implicature is ironically made by violating the maxim of manner because Maria rejects Malvolio's orders and does not clearly express what she intend.

Text (5):

Cesario (Viola): But if she cannot love you, sir

Orsino: I cannot be so answered.

Cesario (Viola): Sooth but you must.

Say that some lady, as perhaps there is,

Hath for your love as great a pang of heart

As you have for Olivia. You cannot love her.

You tell her so. Must she not then be answered? (II, iv, 80-86).

The dialogue is in Orsino's palace where Cesario asks him to consider Olivia's rejection to his love but the latter refuses to accept such a possibility. Viola's speech implicates her love to Orsino. She refers to herself as a lover to Orisino although he does not love her. This particularized conversational implicature is made by violating the maxim of quality because Viola is not telling the truth about her feelings and her true intention.

Text (6):

Cesario (Viola): Madam, I come to whet your gentle thoughts

On his behalf.

Olivia: O by your leave, I pray you.

I bade you never speak again of him.

But would you undertake another suit,

I had rather hear you to solicit that

Than music from spheres (III, I, 101-107).

Cesario tells Olivia that he comes bearing Orsino's affections but she wants to hear no more of it. Olivia tells him that it would be music to her ears to listen to him talking about someone else's love. Olivia implicates that she wants him to talk about his love to her and insinuates her deep attraction towards Cesario. This generalized conversational implicature is made by flouting the maxim of manner because Olivia's speech is obscure and not clear.

Text (7):

Cesario (Viola): I pity you. 
Olivia: That's a degree to love.

Cesario (Viola): No, not a grize. For 'tis a vulgar proof

That very oft we pity enemies.

Olivia: Why then methinks 'tis time to smile again.

O world, how apt the poor are to be proud!

If one should be a prey, how much the better

To fall before the lion than the wolf. A clock strikes

The clock upbraids me with the waste of time.

Be not afraid, good youth, I will not have you.

And yet when wit and youth is come to harvest,

Your wife is like to reap a proper man.

There lies your way, due west (III, i, 121-133).

Cesario answers Olivia's love with the feelings of pitiness which she also considers as a degree of love but Cesario says it is not so, because we very often pity our enemies even though we hate them.

Olivia is now desperate and knows that she speaks in vain but she is glade that she falls a prey before the lion than the wolf and that the strike of the clock announces the time she wastes. She implicates that it is a good think that her heart is broken by a noble man and that all the time she spends trying to convince Cesario of her love is nothing but a waste. This generalized conversational implicature is made by flouting the maxim of manner because Olivia's speech is not entirely clear, it indirectly represented.

Table (4) below shows that generalized conversational type of implicature takes the highest position of usage in the play. Because of the play's theme as a romantic- comedy, the nature of contexts is mostly general. There is only one case of conventional implicature because no many specific contexts are presented in the play.

Table 4. Types of Implicature in Twelfth Night

\begin{tabular}{lll}
\hline Types of Implicature & Number of Occurrences & $\%$ \\
\hline Generalized Conversational Implicature & 18 & 65.51 \\
Particularized Conversational Implicature & 9 & 28.57 \\
Conventional Implicature & 1 & 3.44 \\
Total & 28 & 100 \\
\hline
\end{tabular}

Table (5) below shows that the most flouted maxim is the quality maxim and the least flouted is the maxim of quantity where the number of its occurrence is zero because all the characters are being informative. The maxim of manner scores the second highest number of violation because ambiguity is a feature of the play due to the secrets and double identities.

Table 5. Types of Grice's Maxims Violated in Twelfth Night

\begin{tabular}{lll}
\hline Flouted Maxims & Number of Occurrences & $\%$ \\
\hline Quality & 16 & 57.14 \\
Quantity & 0 & 0 \\
Manner & 11 & 37.93 \\
Relation & 1 & 3.44 \\
Total & 28 & 100 \\
\hline
\end{tabular}

Table (6) shows the characters who produce implicature in Twelfth Night: 
Table 6. Implicature of Characters in Twelfth Night

\begin{tabular}{lll}
\hline Characters & Number of Cases & $\%$ \\
\hline Olivia & 6 & 21.42 \\
Cesario(Viola) & 8 & 28.57 \\
Orsino & 2 & 7.14 \\
Sir Toby & 3 & 10.71 \\
Maria & 3 & 10.71 \\
Feste & 3 & 10.71 \\
Sir Andrew & 1 & 3.57 \\
Malvolio & 1 & 3.57 \\
Sebastian & 1 & 3.57 \\
Total & 28 & 100 \\
\hline
\end{tabular}

The two characters that use implicatures more than others are Olivia and Cesario (Viola) because they are the ones with hidden intentions, the former is in love and tries to declare her love and the latter is disguised and in love. The majority of characters whose performance steers the course of events in the play are uneducated and of low class.

\section{Comparisons}

There are some comparisons between Shakespeare's Hamlet and Twelfth Night that are found through analyzing the selected plays.

\subsection{Generalized conversational implicature in Hamlet and Twelfth Night}

The total cases of implicature in Hamlet is 29 and that in Twelfth Night is 28. Thus, Hypothesis (1) is refuted. The number of implicature cases in Hamlet is bigger than that in Twelfth Night.

According to the results of the analysis in sections three and four, the total number of implicature is (57). There are (15) cases of generalized conversational implicature in Hamlet and (18) cases of the same type in Twelfth Night. Implicature in Hamlet is performed by upper class characters like Hamlet, The king, and Polonius who use implicature to achieve their aims indirectly by saying something and meaning something else. Characters of middle class like Horatio, Rosencrantz, and Guildenstern do not use implicatures because they have no hidden intentions. It is obvious that the female characters like Gertrude and Ophelia use no implicatures because they do not have any aims to be achieved.

In Twelfth Night generalized conversational implicatures are made mostly by the main characters Olivia and Cesario (Viola) because they have hidden intentions; the former is in love and the latter is disguised and not showing her true identity. Hypothesis (2) is accepted. Generation of implicatures by the characters in the two plays is highly determined by social factors in both Hamlet and Twelfth Night (Table 7):

Table 7. Characters and Generalized Conversational Implicature in Hamlet and Twelfth Night

\begin{tabular}{llllll}
\hline Characters in Hamlet & Number of cases & $\%$ & Characters in Twelfth Night & Number of cases & $\%$ \\
\hline Hamlet & 11 & 73.33 & Olivia & 5 & 26.31 \\
King & 2 & 14.28 & Cesario (Viola) & 3 & 16.66 \\
Polonius & 1 & 7.14 & Orsino & 2 & 10.52 \\
Francisco & 1 & 7.14 & Sir Toby & 3 & 16.66 \\
& & & Sir Andrew & 1 & 5.26 \\
& & & Malvolio & 1 & 5.26 \\
& & & Sebastian & 1 & 5.26 \\
Total & & Feste & 2 & 10.52 \\
\hline
\end{tabular}

Hypothesis (3) is refuted. Hamlet and Olivia use implicature more than the other characters in the plays.

\subsection{Particularized Conversational Implicature in Hamlet and Twelfth Night}

Among the (57) cases of implicature, there are (13) cases of particularized conversational implicature in Hamlet mostly made by Hamlet as he is the character with specific intentions and his intentions justify his use of particular contexts in order to achieve his aims. 
In Twelfth Night, there are (9) cases of particularized conversational implicatures mostly made by Cesario (Viola) as a character with a hidden identity that needs to use particular contexts to achieve her aims and intentions, and Maria whose character is witty and deceitful. Thus, Shakespeare makes a great balance in the distribution of types of implicature on the characters (Table 8).

Table 8. Characters and Particularized Conversational Implicature in Hamlet and Twelfth Night

\begin{tabular}{lcclcc}
\hline Characters in Hamlet & Number of cases & $\%$ & Characters in Twelfth Night & Number of cases & $\%$ \\
\hline Hamlet & 9 & 78.57 & Olivia & 1 & 11.11 \\
King & 3 & 14.28 & Cesario (Viola) & 5 & 55.55 \\
Polonius & 1 & 7.14 & Maria & 3 & 33.33 \\
Total & 13 & 100 & & 9 & 100 \\
\hline
\end{tabular}

Thus, Hypothesis (4) is refuted. The most used type of implicature is the generalized conversational one.

\subsection{Conventional Implicature in Hamlet and Twelfth Night}

There is only one case of conventional implicature made in each one of the selected plays because it requires a very specific context. Shakespeare uses a very limited number of specified contexts in the two plays (Table 9).

Table 9. Conventional Implicature in Hamlet and Twelfth Night

\begin{tabular}{ll}
\hline The Play & Number of cases \\
\hline Hamlet & 1 \\
Twelfth Night & 1 \\
\hline
\end{tabular}

\subsection{The violated Maxims in Hamlet and Twelfth Night}

Grice's maxims of conversation are violated differently for different intentions in the two plays. The analysis of the selected plays in sections three and four shows that the most violated maxim is the maxim of quality. Shakespeare violates the quality maxim in Twelfth Night at the mouth of his characters more than he does in Hamlet because the theme of the former's theme is love and it is a comedy where characters are unlikely to be truthful, while the latter's theme is revenge where the use of untruthful speech is related to conspiracies. Hypothesis (5) is accepted. The purpose of using implicatures differs in the two selected plays (Table 10)

Table 10. The Violated Maxims in Hamlet and Twelfth Night

\begin{tabular}{llllc}
\hline The Maxim & Number of cases in Hamlet & $\%$ & Number of cases in Twelfth Night & $\%$ \\
\hline Quality & 15 & 51.72 & 16 & 57.14 \\
Quantity & 0 & 0 & 0 & 0 \\
Manner & 7 & 24.13 & 11 & 39.28 \\
Relation & 7 & 24.13 & 1 & 3.57 \\
Total & 29 & 100 & 28 & 100 \\
\hline
\end{tabular}

Thus, Hypothesis (6) is accepted. Implicature is generated from flouting Grice's maxims. In addition, Hypothesis (7) is rejected. Most of the cases of implicatures are made by violating the maxim of quality in the two plays.

\section{Conclusions}

By analyzing Shakespeare's Hamlet and Twelfth Night, the following conclusions are arrived at:

1 - Implicature is mainly generated by violating Grice's maxims.

2- Most of the cases of implicatures are made by violating the maxim of quality in the two plays.

3- The number of implications in Hamlet is larger than the number in Twelfth Night despite the fact that the former is a tragedy and the latter is a comedy.

4- The most used type of implicature is the generalized conversational one. 
5- Generation of implicatures by the characters in the two plays is highly determined by social factors, that is, the implicatures used in Hamlet are more sophisticated than the ones used in Twelfth Night. In Hamlet the social factors are determined by the royal state of the main characters while in Twelfth Night the dominant atmosphere is that of servants and uneducated people despite the fact that the main characters are high class nobles.

6- Using implicatures may either indicate the character's politeness or rudeness. In Hamlet, even though Hamlet is so angry at his mother, his speech is polite and respectful because of the status that combines the two characters.

7- Irony is used to Achieve Implicature

8- The purpose of using implicatures differs in the two selected plays.

9- Context is the corner stone for the generation of implicatures

10- Some characters implicate by repeating other characters' words or by being ironic. Hamlet's repetition of his mother's words (it is common) indicates the very opposite, that he disagrees and it is not common. Most of the ironic implications are made in Twelfth Night because of its theme as a romantic-comedy play.

11- Ironic scenes are mostly made by saying something and implying something else.

\section{References}

Akmajian, A., Demers, R., Farmer, A., \& Harnish, R. (2001). Linguistics: An Introduction to Language and Communication. Massachusetts: The MIT Press.

Algburi, B. Y. J., \& Zainab, K. I. (2021). Defamation in English and Arabic: A Pragmatic Contrastive Study. International Linguistics Research, 4(2), 31-45. https://doi.org/10.30560/ilr.v4n2p31

Allan, K. (1989). Linguistic Meaning. Vol. 1. London and New York: Routledge.

Al-Seady, M. J. B. (1998). Comparative Education: Some Basic Contributions of Islamic Education to Western Educational Thought. Al-Qadisiya Journal, 3(2), 82-89.

Al-Seady, M. J. B., \& Mohammed, K. A. Al-Sehlani (2002). Collocation in Three Texts of the Absurd: A Stylistic Comparative Cohesive Study. Journal of Al-Qadisiya for Educational Sciences, 3(2), 34-44.

Al-Sheikh, Z. K. (2006a). Iraqi EFL Performance in using evidentiality. Journal of University of Thi-Qar, 2(3), 68-86.

Al-Sheikh, Z. K. (2006b). The Ability of Iraqi Undergraduates to Recognize and Produce Confusing Words in English. Journal of University of Thi-Qar, 2(3), 68-85.

Ariel, M. (2008). Pragmatics and Grammar. Cambridge: CUP. https://doi.org/10.1017/CBO9780511791314

Bahrami, A. (1999). A Dictionary of Discourse Analysis. Tehran: Rahnama.

Barbe, K. (1995). Irony in Context. Amsterdam: John Benjamine. https://doi.org/10.1075/pbns.34

Betti, Mohammed J. (2013). A Literary Analysis of Ten Plays. Diwaniya: Nippur.

Betti, M. (2015). An Introduction to Drama. Diwaniya: Dar Nippur.

Betti, M. J., \& Mirdas, S. A. (2016). A Stylistic Study of Irony in Shakespeare's Hamlet and Ben Johnson's Volpone. Unpublished MA Thesis, College of Education, University of Thi-Qar.

Betti, Mohammed J. (2002). A Literary Analysis of Shakespeare's Hamlet and Twelfth Night, and Goldsmith's She Stoops to Conquer. Nasiriya : Afaaq.

Betti, Mohammed J., \& Igaab, Z. K. (2018). A Contrastive Study of Modulation in English and Arabic. International Journal of English and Cultural Studies, 1(1), 30-45. https://doi.org/10.11114/ijecs.v1i1.3120

Betti, Mohammed J., Igaab, Z. K., \& Al-Ghizzi, M. T. H. (2018). The Iraqi EFL Learners' Use of Permission, Obligation and Prohibition. International Journal of English Linguistics, 8(3), 251-269. https://doi.org/10.5539/ijel.v8n3p251

Betti, Mohammed J., \& Yaseen, K. S. (2020). The Iraqi EFL Learners' Use of Conversational Maxims at the University Level. Education, Language and Sociology Research, 1(1), 43-60. https://doi.org/10.22158/elsr.v1n1p43

Betti, Mohammed J., \& Hasan, A. A. (2020). The Iraqi EFL Learners' Ability to Use Speech Acts in MA and Ph.D. Theses Defense. Education, Language and Sociology Research, 1(2), 41-65. https://doi.org/10.22158/elsr.v1n2p41

Bianchi, C. (2013). Implicating. In Sibsa, m. and Turner, K. (Eds). Pragmatics of Speech Actions. Berlin: Gruyter 
Mouton.

Birner, B. (2013). Introduction to Pragmatics. Oxford: Wily Blackwell. https://doi.org/10.7202/1017210ar

Black, E. (2006). Pragmatic Stylistics. Edinburgh: Edinburgh University Press.

Blackwell, S. (2003). Implicatures in Discourse: The Case of Spanish Anaphora. Amsterdam: John Benjamin. https://doi.org/10.1075/pbns.105

Borjesson, K. (2014). The Semantics-Pragmatics Controversy. Boston: Gruyter Mouton. https://doi.org/10.1515/9783110333411

Bousfield, D. (2008). Impoliteness in Interaction. Amsterdam: John Benjamin. https://doi.org/10.1075/pbns.167

Burke, M. (2014). The Routledge Handbook of Stylistics. Routledge: Taylor and Francis Group.

Carston, R. (2002). Thoughts and Utterances: The Pragmatics of Explicit Communication. Oxford: Blackwell. https://doi.org/10.1002/9780470754603

Chapman, S. (2005). Paul Grice, Philosopher and Linguist. New York: Palgrave Macmillan. https://doi.org/10.1057/9780230005853

Clark, D. (2001). Context, Cognition, and defeaness. Gallaudent: Gallaudent University Press.

Collavin, E. (2011). Foundations of Pragmatics. Berlin/ Boston: Gruyter Mouton. https://doi.org/10.1515/9783110214260.373

Cruse, A. (2006). A Glossary of Semantics and Pragmatics. Edinburgh: Edinburgh University Press.

Curzan, A., \& Adams, M. (2012). How English Works: A Linguistic Introductory (3 ${ }^{\text {rd }}$ ed.). London: Longman.

Cutting, J. (2002). Pragmatics and Discourse: A Resource Book for Students. London: Routledge Taylor and Francis Group.

Feng, G. (2010). A Theory of Conventional Implicature and Pragmatic Markers in Chinese. London: Emerald. https://doi.org/10.1163/9789004253179

Fischer, G., \& Greiner, B. (2007). The Play Within The Play: The Performance of Meta-Theatre and Self Reflection. Amsterdam: Editions Rodopi. https://doi.org/10.1163/9789401204842

Fraser, B. (2010). New Approaches to Hedging. Britain: Emerald Group.

Gazdar, G. (1979). Pragmatics: Implicatures, Presupposition, and Logical Form. New York: Academic Press.

Geurts, B. (2010). Quantity Implicatures. New York: Cambridge University Press. https://doi.org/10.1017/CBO9780511975158

Grice, H. P. (1975). Logic and Conversation. In P. Cole and J. L. Morgan (Eds.), Syntax and Semantics: Speech Acts., 3, 41-58. London: Academic Press. https://doi.org/10.1163/9789004368811_003

Griffiths, P. (2006). An Introduction to English Semantics and Pragmatics. Edinburgh: Edinburgh University Press.

Grundy, P. (2000). Doing Pragmatics (2 ${ }^{\text {nd }}$ ed.). London: Arnold Publishing.

Halliday, M., \& Hasan, R. (1989). Language, Context and Text: Aspects of Language in a Social-Semiotic Perspective. Oxford: Oxford University Press.

Hebron, M. (2004). Mastering the Language of Literature. London: Palgrave Macmillan. https://doi.org/10.1007/978-1-137-06380-9

Huang, Y. (2007). Pragmatics. Oxford: Oxford University Press.

Huang, Y. (2017). The Oxford Handbook of Pragmatics. Oxford: Oxford University Press.

Hyland, K. (1998). Hedging in Scientific Research Articles. Amsterdam: John Benjamin. https://doi.org/10.1075/pbns.54

Igaab, Zainab Kadim (2010). A Contrastive Study of Metathesis in English and Arabic. Wasit: Journal of College of Education, 1(7), 152-172.

Igaab, Z. K. (2015). Apposition in English and Arabic: A Contrastive Study. University of Thi-Qar, College of Education for Humanities, 5(4), 110-143.

Igaab, Z. K., \& Al-Manhalawey, M. S. O.(2010). Case in English and Arabic: A Contrastive Study. Journal of University of Thi-Qar, College of Arts, 1(1), 1-54. 
Igaab, Zainab Kadim and Tarrad, Intisar Raham (2019). Pronouns in English and Arabic: A Contrastive Study. English Language and Literature Studies, 9(1), 53-69. https://doi.org/10.5539/ells.v9n1p53

Kenesei, I., \& Harnish, R. (2001). Perspectives on Semantics, Pragmatics and Discourse. Amsterdam: John Benjamin. https://doi.org/10.1075/pbns.90

Khosravizadeh, P., \& Sadehvandi, N. (2011). Some Instances of Violation and Flouting of the Maxims of Quantity by the Main Characters (Barry and Tim) in Dinner for Schmucks. International Conference on Language, Literature, and Linguistics, 26, 122-127.

Kortmann, B. (2020). English Linguistics: Essentials (2 $2^{\text {nd }}$ ed.). Freiburg: J. B. Metzler Verlag. https://doi.org/10.1007/978-3-476-05678-8

Kranich, S. (2016). Contrastive Pragmatics and Translation. Amsterdam: John Benjamin. https://doi.org/10.1075/pbns.261

Kroeger, P. (2018). Analyzing Meaning: An Introduction to Semantics and Pragmatics. Berlin: Freie University.

Kroeger, P. (2019). Analysing Meaning: An Introduction to Semantics and Pragmatics (2 $\left.2^{\text {nd }} e d\right)$. Berlin: Language Science Press.

Lamb, S. (2000). Cliffs complete Shakespeare's Hamlet. New York: Hungry Minds.

Lamb, S. (2000). Cliffs Complete Shakespeare's Twelfth Night. New York: Hungry Minds.

Leech, G. (1983). Principles of Pragmatics. London: Longman.

Leech, G. (2008). Language in Literature: Style and Foregrounding. New York: Routledge.

Leech, G. (2014). The Pragmatics of Politeness. Oxford: Oxford University Press. https://doi.org/10.1093/acprof:oso/9780195341386.001.0001

Leung, S. (2002). Language and Meaning in Human Perspective. London: England.

Levinson, S. (1983). Pragmatics. Cambridge: Cambridge University Press. https://doi.org/10.1017/CBO9780511813313

Li, Q. (2015). The Application of the Cooperative Principle on Oral English Teaching. International Journal on Studies in English Language and Literature, 3, 39-48.

McCready, E. (2015). Reliability in Pragmatics. Oxford: Oxford University Press. https://doi.org/10.1093/acprof:oso/9780198702832.001.0001

Meibauer, J. (2012). What is a Context. Amsterdam: John Benjamin. https://doi.org/10.1075/la.196.04mei

Mey, J. (2001). Pragmatics: An Introduction $\left(2^{\text {nd }}\right.$ ed). Oxford: Blackwell Publishing. https://doi.org/10.1016/S0378-2166(00)00016-3

Mufwene, S., Francis, E., \& Wheeler, R. (2005). Polymorphous Linguistics. Cambridge: Massachusetts Institute of Technology.

O'grady, W., \& Archibald, J. (2016). Contemporary Linguistic Analysis. Pearson Learning Solutions.

O'keeffe, A. Clancy, B. and Adolphs, S. (2011). Introducing Pragmatics in Use. London: Routledge Taylor and Francis Group. https://doi.org/10.4324/9780203830949

Paltridge, B. (2012). Discourse Analysis (2 ${ }^{\text {nd }}$ ed.). New Delhi: Bloomsbury.

Pollock, J. (2020). The Architecture of Context and Context-Sensitivity: Perspectives from Philosophy, Linguistics and Logic. Switzerland: Springer Nature Switzerland AG. https://doi.org/10.1007/978-3-030-34485-6_13

Ricoeur, P. (1977). The Rule of Metaphor: The Creation of Meaning in Language. New York: University of Toronto Press.

Riemer, N. (2010). Introductory Semantics. Cambridge: Cambridge University Press. https://doi.org/10.1017/CBO9780511808883

Saeed, J. (2016). Semantics ( $4^{\text {th }}$ ed). New Delhi: Wiley Blackwell.

Salman, H. S., \& Betti, Mohammed J. (2020). Politeness and Face Threatening Acts in Iraqi EFL learners' Conversations. GLOSSA, 3(8), 221-233.

Schiffer, S. (1972). Meaning. Oxford: The Clarendon Press.

Schmitz, H. (2008). Accentuation and Interpretation. New York: Palgrave Macmillan. 
https://doi.org/10.1057/9780230592568

Searl, J. (1977). The Philosophy of Language. Oxford: Oxford University Press.

Searl, J. (1979). Expression and Meaning. Cambridge: Cambridge University Press. https://doi.org/10.1017/CBO9780511609213

Senfit, G. (2014). Understanding Pragmatics. London: Routledge Taylor and Francis Group. https://doi.org/10.4324/9780203776476

Sibsa, M. and Ken, T. (2013). Introduction in Pragmatics of Speech Actions. Berlin/ Boston: Gruyter Mouton. https://doi.org/10.1515/9783110214383

Stalnaker, R. (2014). Context. Oxford: Oxford University Press. https://doi.org/10.1093/acprof:oso/9780199645169.001.0001

Strassler, J. (1982). Idioms in English: A Pragmatic Analysis. Tubingen: Gunter Narr Verlag Tubingen.

Thomas, J. (1995). Meaning in Interaction: An Introduction to Pragmatics. Longman.

Verdonk, P. (2013). The Stylistics of Poetry: Context, Cognition, Discourse, History. Bloonsbury Publishing PLC.

Widdowson, H. (2004). Text, Context, Pretext: Critical Issues in Discourse Analysis. Oxford: Blackwell Publishing. https://doi.org/10.1002/9780470758427

Wiegandt, K. (2004). Theories of Irony. Norderstedt: Grin Verlag.

Wilson, D., \& Sperber, D. (2012). Meaning and Relevance. Cambridge: Cambridge University Press. https://doi.org/10.1017/CBO9781139028370

Yule, G. (1996). Pragmatics. Oxford: Oxford University Press.

Yule, G. (2020). The study of Language ( $7^{\text {th }}$ ed.). Cambridge: Cambridge University Press.

Zufferey, S., Moeschler, J., \& Reboul, A. (2019). Implicature. Cambridge: Cambridge University Press. https://doi.org/10.1017/9781316410875

\section{Copyrights}

Copyright for this article is retained by the author(s), with first publication rights granted to the journal.

This is an open-access article distributed under the terms and conditions of the Creative Commons Attribution license (http://creativecommons.org/licenses/by/4.0/). 